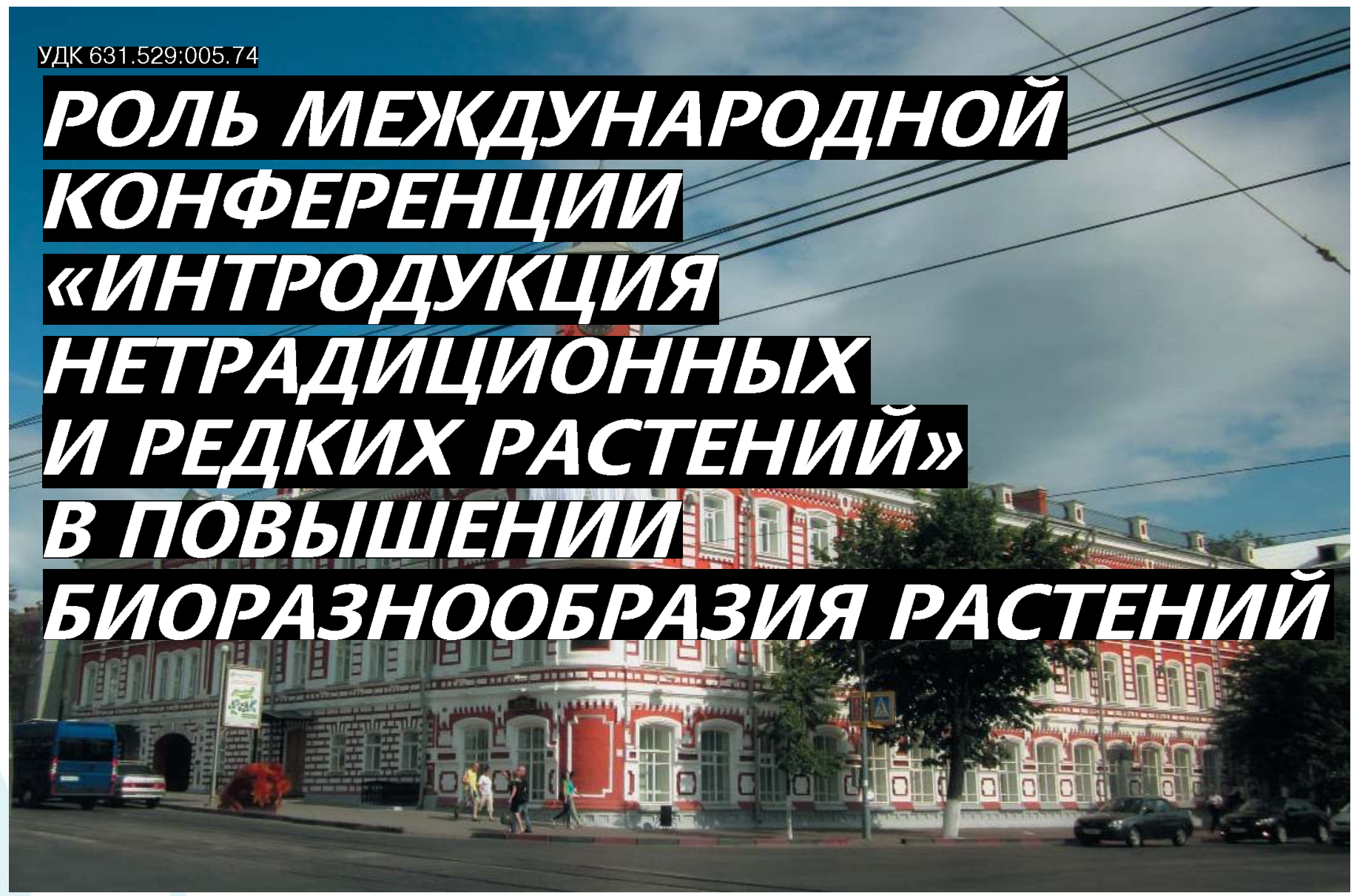

Немиев С.Н.1 - доктор С.-х. наук, директор

Гинс М.С.2 - лауреат Государственной премии РФ, доктор биологических наук, зав. отделом физиологии и биохимии растений

Гинс В.К.2 - лауреат Государственной премии РФ, Заслуженный деятель науки, доктор биологических наук, зав. лаб. биохимии и биотехнологии функциональных продуктов

Науменко T.C. 2 - кандидат С.-Х. наук,

с.н.с. отдела планирования и координачии нир

\section{1 ГНУ УЛЬЯнОВСКИй НИИ}

сельского хозяйства Россельхозакадемии

433315, Россия, Ульяновская область, Ульяновский район, п.Тимирязевский, ул.Институтская, д. 19

тел./факс (8422) 47-87-55; (84254) 34-7-33; (84254) 34-7-32

E-mail: ulniish@mv.ru

2 ГнУ Всероссийский нии селекиии и семеноводства овомных культур

143080, Россия, Московская область, п. ВНИИССОк,

ул. Селекиионная, 0.74

тел. 8(495) 599-24-42, факс 8(495)599-22-77

E-mail: info@vniissok.ru

С 25 по 29 июня 2012 года на базе Ульяновского научноисследовательского института сельского хозяйства состоялась юбилейная Х Международная научнометодическая конференция «Интродукция нетрадиционных и редких растений», посвященная памяти академика Россельхозакадемии Немцева Н.С.

Ключевые слова: нетрадиционные растения, интродукция, селекиия, физиология, биохимия, конферениия.
$\mathbf{V}$ родто проведенения Х Менференции «Интродукция нетрадиционных и редких растений» - Ульяновский научно-исследовательский институт сельского хозяйства Россельхозакадемии было выбрано не случайно.

Основы научно-исследовательской деятельности здесь были заложены еще К.А. Тимирязевым, который по заданию Д.И. Менделеева проводил исследования по влиянию минерального питания на фотосинтез и урожайность ряда сельскохозяйственных культур. В течение пяти лет (с 1933 по 1938 годы) возглавлял государственное сортоиспытание В.Н. Ремесло, впоследствии дважды Герой Социалистического Труда, академик ВАСХНИЛ и АН СССР, внесший большой вклад в становлении селекции и семеноводства сельскохозяйственных растений этого института. Второе дыхание в развитие научно-исследовательских работ обеспечил Николай Сергеевич Немцев, в результате чего Ульяновский научно-исследовательский институт сельского хозяйства 
вошел в число лучших институтов Россельхозакадемии. Достаточно сказать, что работы ученых этого института дважды отмечены Государственными премиями РФ в области науки и техники в 1995 и 2000 годах. В 2008 году за счет внедрения новых сортов овса около $90 \%$ посевных земель Ульяновской области были заняты этими сортами.

Конференция открылась приветствием председателя оргкомитета, Президента АНИРР, лауреата Государственной премии РФ, Заслуженного деятеля науки РФ, доктора с.-х. наук, профессора П.Ф. Кононкова, в котором была подчеркнута значимость научно-производственной деятельности Ульяновского НИИСХ и роль директора, академика РАСХН Немцева Н.С. в развитии сельского хозяйства Поволжья. Так в Государственный реестр селекционных достижений допущенных к использованию, по состоянию на 2012 год внесено 18 сортов зерновых и зернобобовых культур селекции института. По итогам работы за 2008 год завершенная разработка ГнУ Ульяновский НИИСХ «Методология проектирования и проекты базовых элементов адаптивно-ландшафтных систем земледелия и агротехнологий для товаропроизводителей различной специализации Ульяновской области» был признана лучшей в Отделении земледелия Россеьхозакадемии. В 2010 году институт награжден Золотой медалью MCX России «За вклад в развитие агропромышленного комплекса России».

С пожеланиями успешной работы участникам конференции выступил первый заместитель Председателя Правительства Ульяновской области Александр Петрович Пинков. Он отметил огромный вклад ученых Ульяновской опытной станции, а затем организованного на его основе Ульяновского НИИСХ, коллективом которого с 1975 года до 2008 года бессменно руководил Николай Сергеевич Немцев. Под его руководством созданы системы адаптивно-ландшафтного земледелия и разработаны ресурсосберегающие

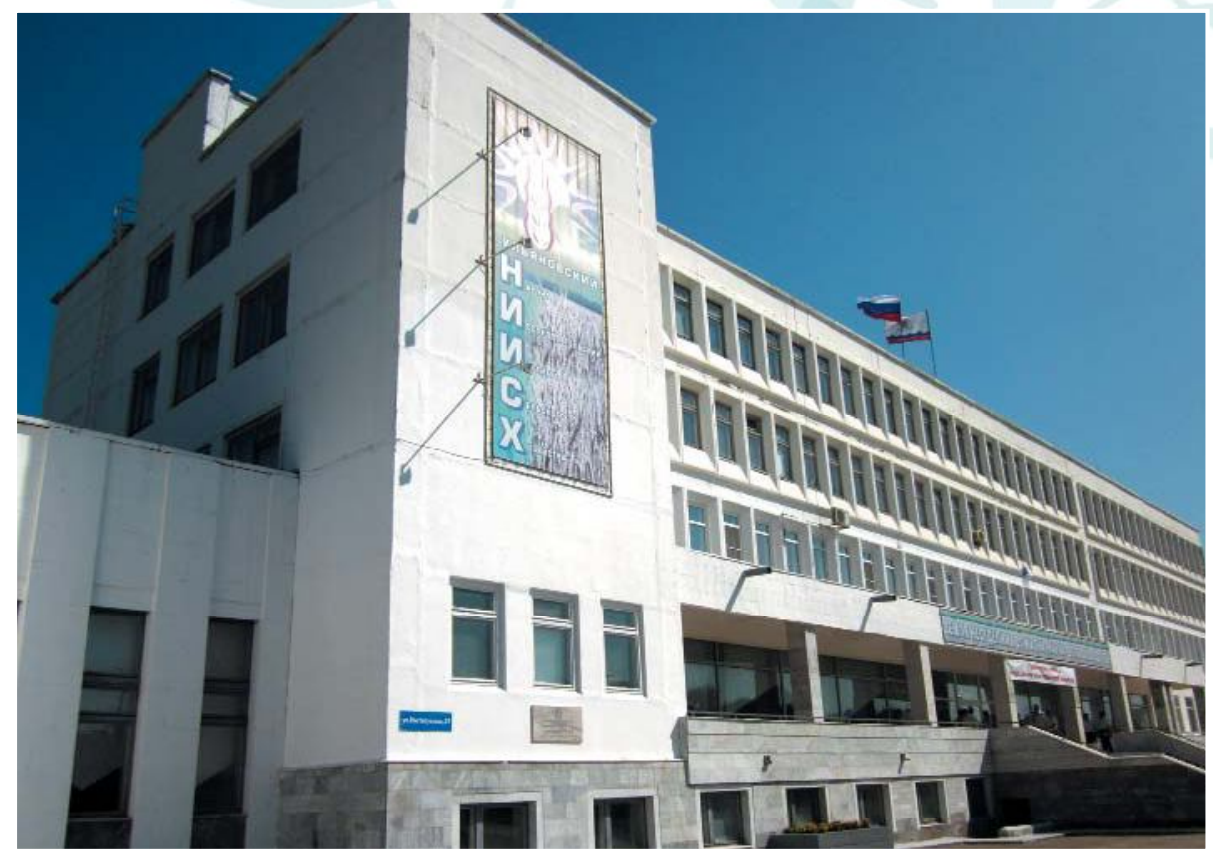

технологии возделывания зерновых, лекарственных и нетрадиционных растений и улучшения плодородия почв. Помимо научной работы Н.C. Немцев занимался социальными проблемами сотрудников института, создав на базе поселка Тимирязевский агрогородок.

Директор ВНИИССОК, академик Россельхозакадемии Пивоваров В.Ф. обратил внимание участников конференции на проблемы и перспективы развития сельского хозяйства, в том числе овощеводства и указал место интродуцированных овощных растений в питании и оздоровлении человека. Он отметил, что в повышении каче-

ства растительной продукции, эффективности растениеводства важная роль принадлежит селекции и семеноводству, задача которых - создание новых отечественных конкурентоспособных сортов традиционных и интродуцированных растений.

В приветствии Чепухина А.В. прозвучала оптимистическая нота, что целенаправленный и результативный труд коллектива НИИСХ позволил регулярно создавать новые сорта пшеницы, овса и других культур, которые районированы во многих регионах страны. Также он подтвердил, что будут найдены средства для развития современно-

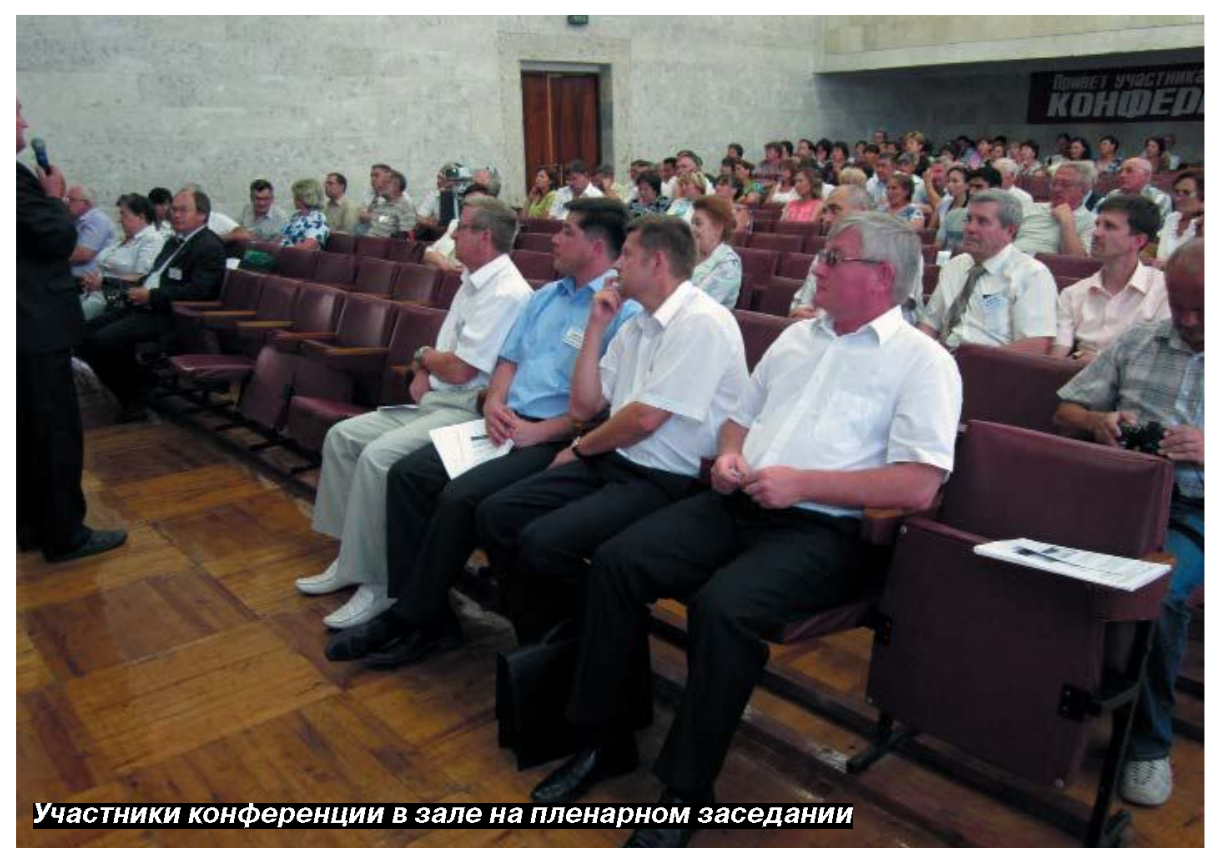




\section{ИНФОРМАЦИОННЫЕ СООБЩЕНИЯ}

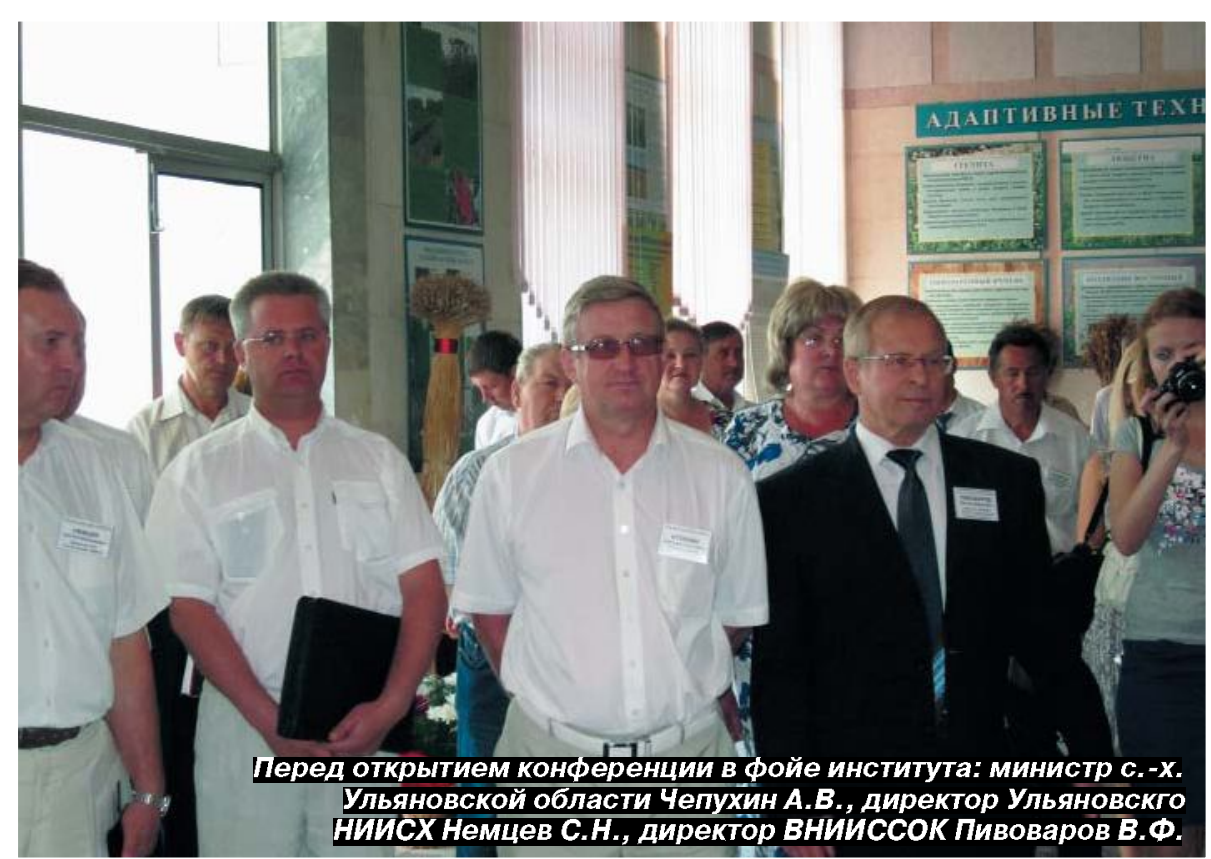

го научного агрогородка и выразил уверенность, что со временем он станет образцом для населенных пунктов России, а в научном плане организатором фундаментальных и прикладных исследований в земледелии.

В своем докладе директор института Немцев С.Н. подробно отразил основные итоги научно-производственной деятельности ГНУ Ульяновского НИИСХ. За последние 6 лет институтом были разработаны: методология и модель автоматизированного проектирования адаптивно-ландшафтных систем земледелия, обеспечивающие воспроизводство почвенного плодородия, повышение продуктивности земель и рентабельности производства сельскохозяйственных культур для условий лесостепи Поволжья; 8 агротехнологий, 7 приемов, 1 метод и 1 способ возделывания сельскохозяйственных культур, гарантирующие увеличение урожайности на 8-17\% и рентабельное производство высококачественной продукции сельскохозяйственных культур; 2 схемы севооборотов для товаропроизводителей различной специализации, позволяющие повысить продуктивность пашни на 12-15\% и снизить затраты на 8-10\%; 1 сырьевой конвейер для кормопроизводства региона, позволяющий получить продукцию с высокой кормовой ценностью и ститута. Созданные сорта имеют широкое распространение в Ульяновской области и Российской Федерации. По всем сортам в институте ведётся первичное семеноводство. В 2012 году Государственное сортоиспытание проходят пять новых сортов яровой пшеницы Экада 97, Экада 109, Экада 113, Сурская юбилейная, Ярица, три сорта овса - Пируэт, Каприоль и Чалый, новый сорт гороха - Улан. Следует отметить, что новый сорт яровой пшеницы Экада 113, созданный в результате реализации совместной программы «Экада» по созданию новых сортов яровой пшеницы, передан в ГСИ Российской Федерации и Республики Казахстан. Всего отделом селекции, образованном в 1927 году, было выведено около 80 сортов, районировано - 32 .

Институт вносит значительный вклад в интродукцию нетрадиционных и редких для условий региона растений в сельскохозяйственное производство.

В 90-е годы нами была разработана технология возделывания козлятника восточного, ценной многолетней бобовой травы, используемой для получения различных видов высокобелковых объёмистых кормов. С помощью ученых института эта культура была внедрена на площади около 20 тыс.га.

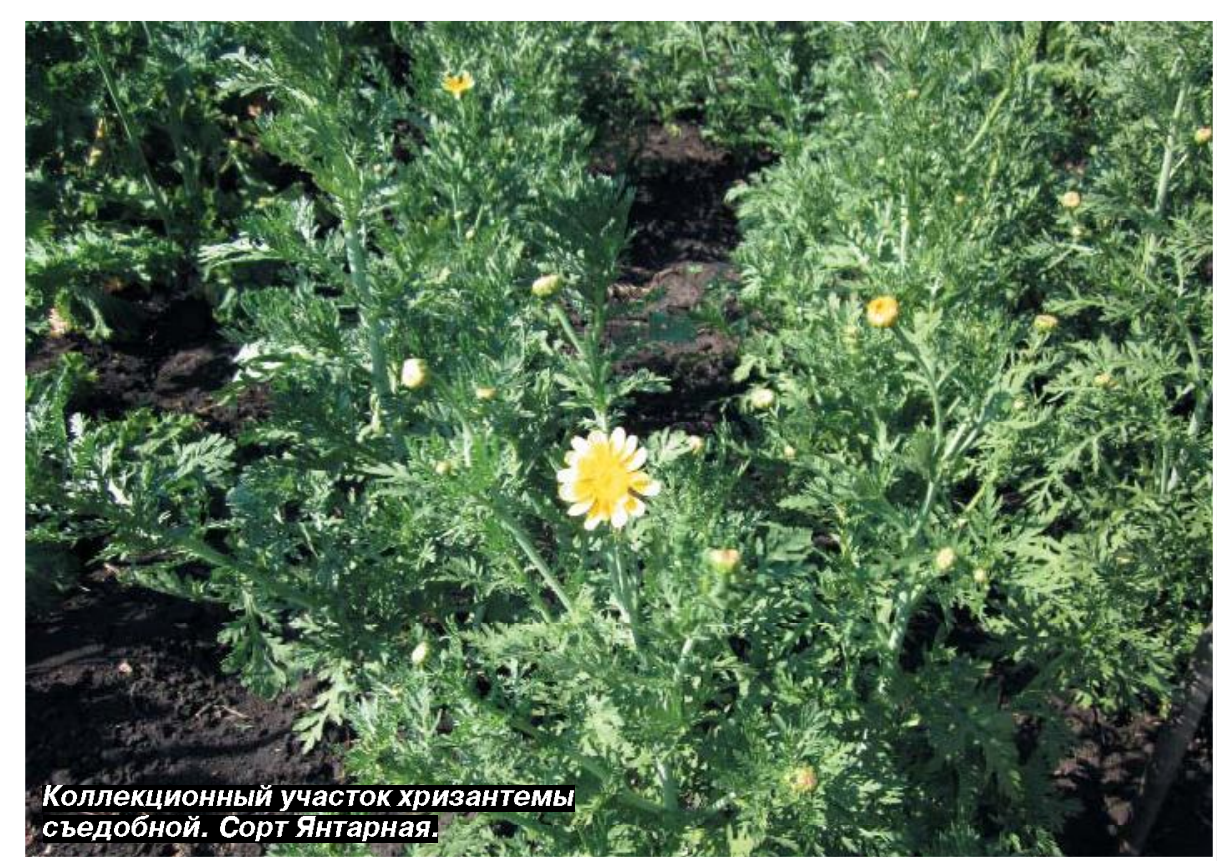




\section{ИНФОРМАЦИОННЫЕ СООБЩЕНИЯ}

В 2007 году разработана технология возделывания многолетней кормовой культуры свербига восточная, которая обеспечивает получение в ранние сроки (с 15 мая) высокобелковой зелёной массы. Способ посева свербиги восточной на корм был запатентован в 2010 году.

Ведутся исследования по усовершенствованию технологии возделывания сорго сахарного. Проводится экологическое испытание сахарного и зернового сорго, сорго-суданковых гибридов для подбора наиболее адаптивных сортов и гибридов этих культур.

Лабораторией многолетних и лекарственных трав с 1995 года ведется работа по возделыванию лекарственных трав. Первоначально был заложен производственный участок календулы лекарственной сорт Кальта площадью в один гектар и шалфея сорт Геницей.

В последующем В агроцентре ВИЛАР был закуплен семенной материал расторопши пятнистой в количестве 35 кг. В 1996 году были заложены первые опыты по изучению технологии этой новой культуры для нашей зоны. На основе полученных данных разработана технология возделывания расторопши пятнистой для условий Среднего Поволжья. В последующие годы ассортимент трав пополнили следую-

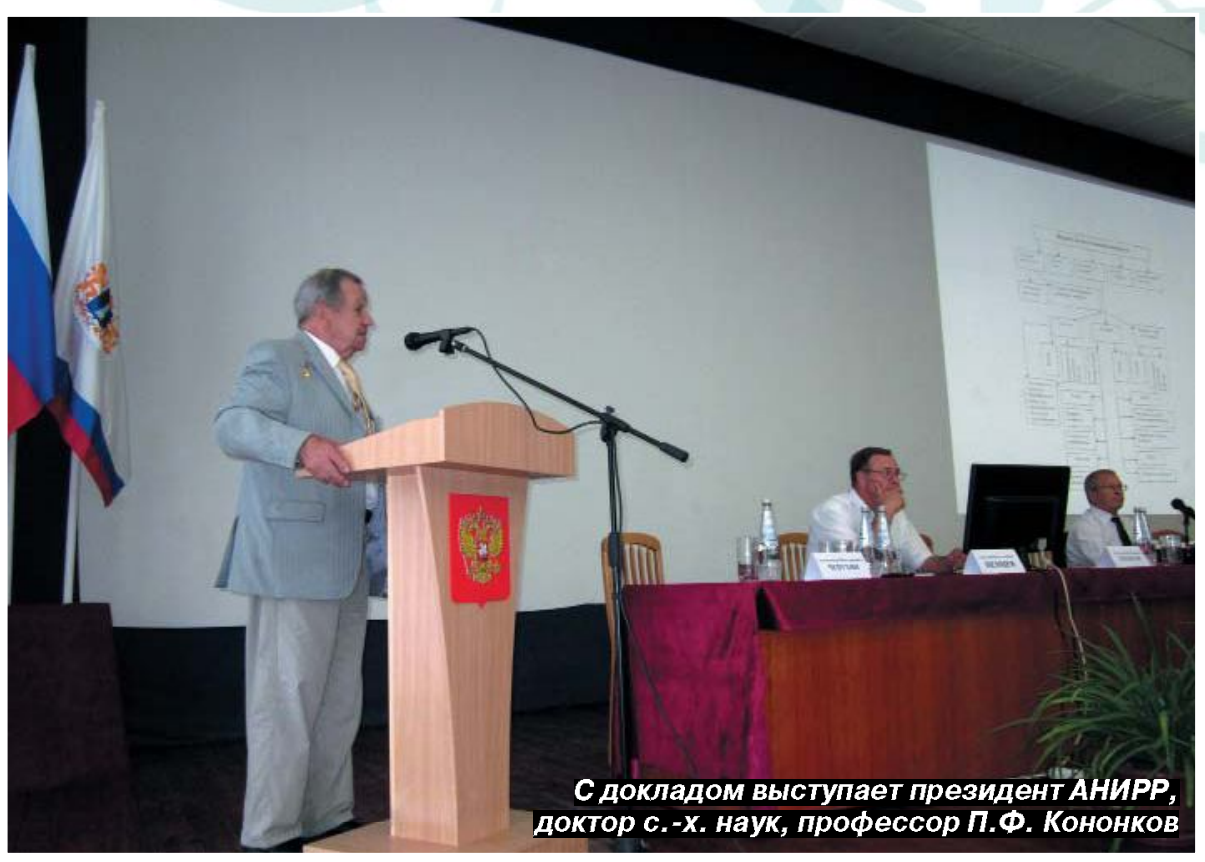

щие культуры - левзея сафлоровидная и валериана лекарственная. В дальнейшем работа по возделыванию этих культур была приостановлена по причине высокой трудоемкости по обработке корней. С 2005 года введены в севооборот Пустырник лекарственный сорт Самарский, тысячелистник Васюринский, лен масличный сорт Северный и эхинацея пурпурная . Ежегодно площади посева лекарственных трав лаборатории составляют от 15 до 25 га. Более половины из этих площадей занимает сорт расторопши пятнистой Дебют. Возделывается расторопша не

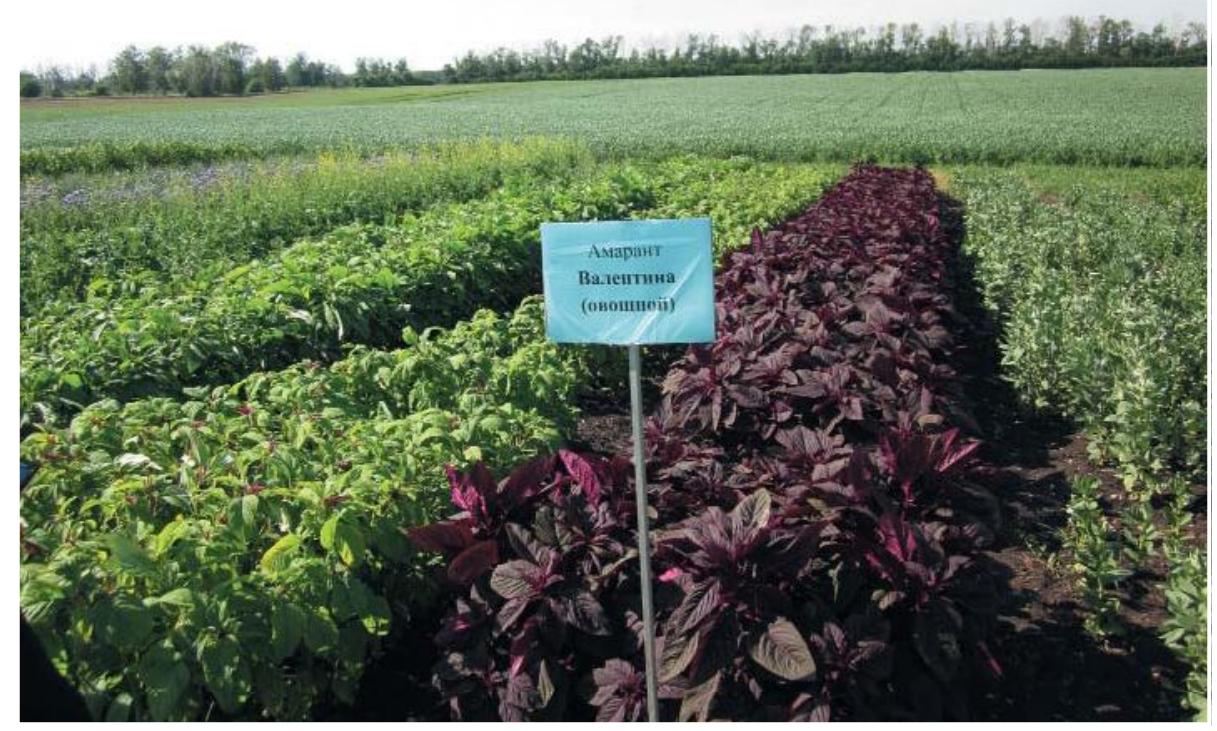

только с целью получения плодов в виде лекарственного сырья. Большая часть полученного урожая идет на семенные цели. Производятся небольшие закладки семенных участков эхинации пурпурной и пустырника Самарского.

Производимое лекарственное сырье (плоды, растительное сырье, цветы) реализуется в различные регионы РФ. Если 2006 году объем производства лекарственного растительного сырья составлял 40 ц, то 2011 году около 80 ц. Ежегодно лабораторией реализуется семян расторопши от 5 до 10 т, льна масличного около 3 т. Возобновлена работа по первичному семеноводству фацелии сорта Ульяновская местная, семена которой пользуются большим спросом у пчеловодов. Разрабатывается медоносный конвейер с использованием фацелии для пчелосемей в Средневолжском регионе.

В лаборатории размножения отдела садоводства ежегодно выращивается около 2000 штук саженцев ред-

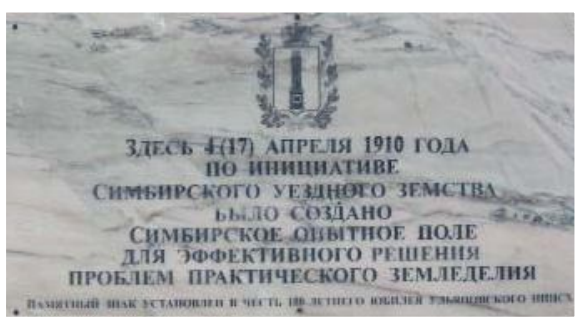




\section{ИНФОРМАЦИОННЫЕ СООБЩЕНИЯ}

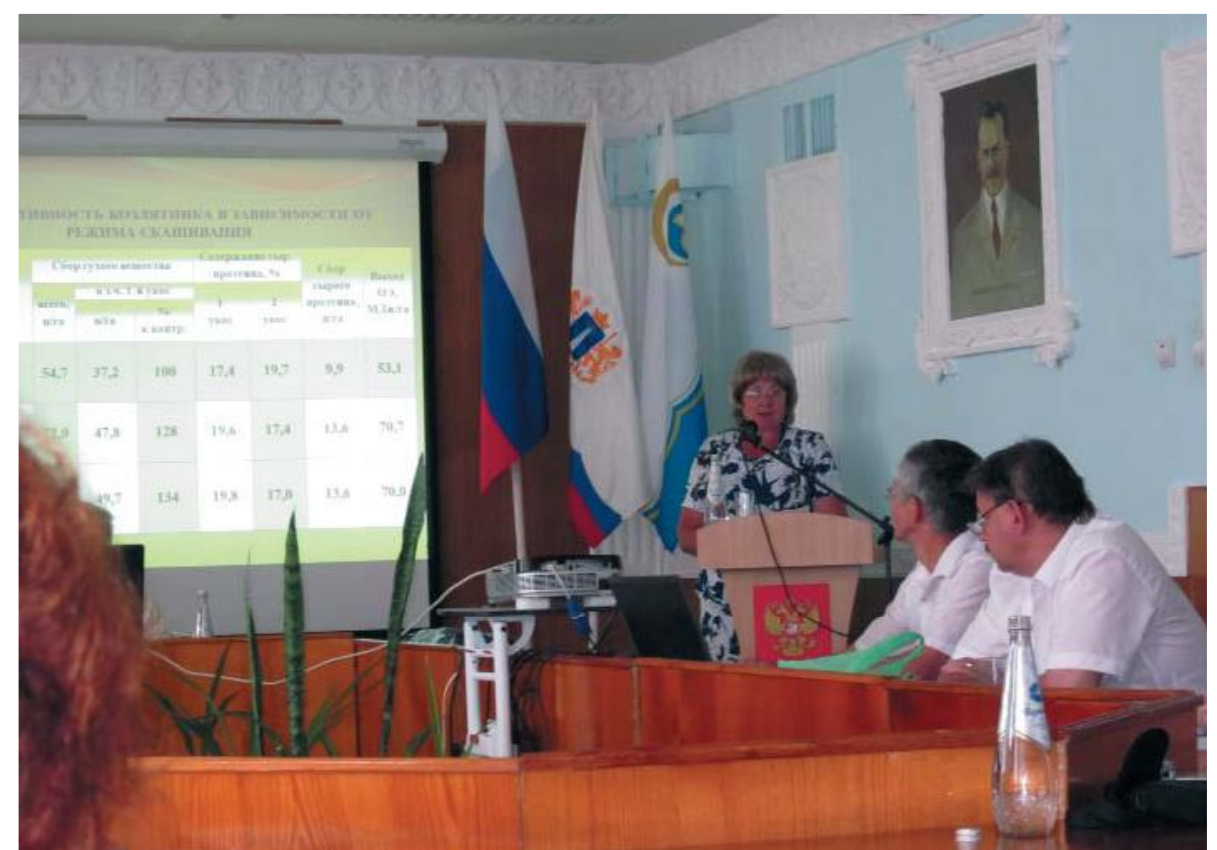

ких малораспространенных культур, которые реализуются в основном садоводам-любителям. На маточнике питомника имеется 12 пород: жимолость сортов Лазурная, Синяя птица, Изюмная, Сергей Лазо, Голубое веретено, Черничка; сирень сортов Мадам Лемуан, Гастелло, Огни Донбасса, Маршал Фош, Бюффорон; калина сортов Таежные рубины и Саузга; облепиха сортов Новинская и Нижегородская сладкая; барбарис сорт Тумберга; черемуха сорт Виргинская; шиповник сорт Витаминный; черноплодная рябина; жасмин; хеномелис; бирючина; ель сизая. Размножение ведется одревесневшими и полуодревесневшими черенками, горизонтальными и вертикальными отводками, а также зеленым черенкованием.

За последние 6 лет институтом получено 10 патентов на новые сорта и 1 патент на изобретение. Расчетная экономическая эффективность по завершенным разработкам в 2006 - 2011 годах составила около 1,5 млрд. рублей.

По результатам исследований в 2006 - 2011 годах издано 409 единиц печатной продукции, в т.ч: «Методология проектирования и проекты базовых элементов адаптивно-ландшафтных систем земледелия и агротехнологий для товаропроизводителей различной специализации Ульяновской области», признанная в 2008 году лучшей завершенной работой Отделения земледелия Россельхозакадемии; 5 монографий; 30 научно-практических и методических руководства, 365 статей.

На базе института организованы и проведены 3 международные и 4 Всероссийские научно-практические конференции. Изданы материалы их работы.

По инициативе Ульяновского НИИСХ в 2011 году организован выпуск регионального научно-практического журнала «Агромир Поволжья» для популяризации инновационных достижений аграрной науки и передовой практики в

Ульяновский НИИСХ достойно представляет Ульяновскую область на сельскохозяйственных выставках не только в России, но и за рубежом. Разработки института демонстрировались на 74 выставках, в т.ч. 7 международных. За участие в выставках институт награждён многочисленными медалями и дипломами различного достоинства (более 15) за успехи, достигнутые в земледелии, селекции, семеноводстве и плодопитомничестве. Минисийской Федерации институт награжден Золотой медалью «За вклад в развитие агропромышленного комплекса России». производстве. стерством сельского хозяйства Рос-
Далее выступил профессор Мордовского ГУ им. Н.П. Огарева Каргин И.Ф. Он рассказал о жизненном пути и основных вехах научной деятельности академика Россельхозакадемии Н.C. Немцева, который внес существенный вклад в развитие аграрной науки Поволжья.

Всего в конференции приняло участие более 100 ученых из 5 стран мира. Научная программа конференции была представлена докладами по интродукции нетрадиционных и редких растений и теоретическим работам по фундаментальным и прикладным проблемам физиологии и биохимии сельскохозяйственных растений.

\section{Научные секции конференции:}

1. Интродукция растений и перспективы их практического использования.

2. Физиологически активные вещества, устойчивость к стрессам, фотосинтетическая и биологическая продуктивность.

3. Генетика, селекция, семеноводство. 4. Рациональное использование известных и поиск новых биологически активных соединений растительного происхождения.

5. Переработка нетрадиционных и лекарственных растений для производства пищевых добавок для функционального питания.

6. Агротехника, механизация и проблемы земледелия.

На заседаниях были заслушаны и обсуждены 20 устных докладов.

Фундаментальные проблемы интродукции нетрадиционного растения амаранта пищевого использования были обстоятельно затронуты в докладе профессора П.Ф. Кононкова. За период с 1991 года во ВНИИССОК по настоящее время создано 9 сортов амаранта, внесенных в государственный реестр селекционных достижений России. В частности такие сорта, как Кизлярец - семенного и силосного назначения, сорт Валентина - овощного и технического назначения, сорта Памя- 


\section{ИНФОРМАЦИОННЫЕ СООБЩЕНИЯ}

ти Коваса, Крепыш и другие овощного направления и четыре сорта декоративного назначения. Именно разработка технологий создания пищевых, в том числе функциональных продуктов, на основе семян и листьев амаранта, как было отмечено в докладе проф. М.С. Гинса способствует широкому внедрению культуры в продовольственный комплекс страны и восполнит потребность в полноценном белке, богатом незаменимыми аминокислотами. На базе высокоантиоксидантного сырья из амаранта во ВНИИССОК отрабатываются технологии производства чайных продуктов, безалкогольных напитков, хлебобулочных и кондитерских изделий совместно с Воронежским государственным аграрным университетом им. императора Петра I и другими ВНИИ России (д.б.н. Дерканосова М.Н., Д.с.-Х.н. Кононков П.Ф., аспиранты Шеламова Н.А., Крючкова М.Ю., к.биол.н. Пиункова и д.биол.н. Коничев А.С.).

Большой интерес вызвал доклад д.с.-х.н. Лысенко из Пензенского НИИСХ по использованию сидеральных удобрений при выращивании картофеля в разные сроки посадки.

В обстоятельном докладе к.б.н. Е.А. Арестовой и А.И. Шабаева отмечалось, что в условиях засушливого Поволжья в дендрарии НИИСХ Юго-Востока интродуцированные виды шиповника из разных стран мира успешно акклиматизируются в новых экологических условиях, которые широко используются в качестве маточников при выращивании растений для декоративного озеленения в различных районах Саратовской области и города Саратова.

об актуальности внедрения в лесные культуры ценных пород древесных интродуцентов, требовательных к плодородию и увлажненности почвы ореха маньчжурского и успешной их интродукции в условиях Поволжья в естественных дубравах Прихоперья на западе Саратовской области, доложила ст. преподаватель А.А. Овчаренко.

Интродукция растений тесно связа-

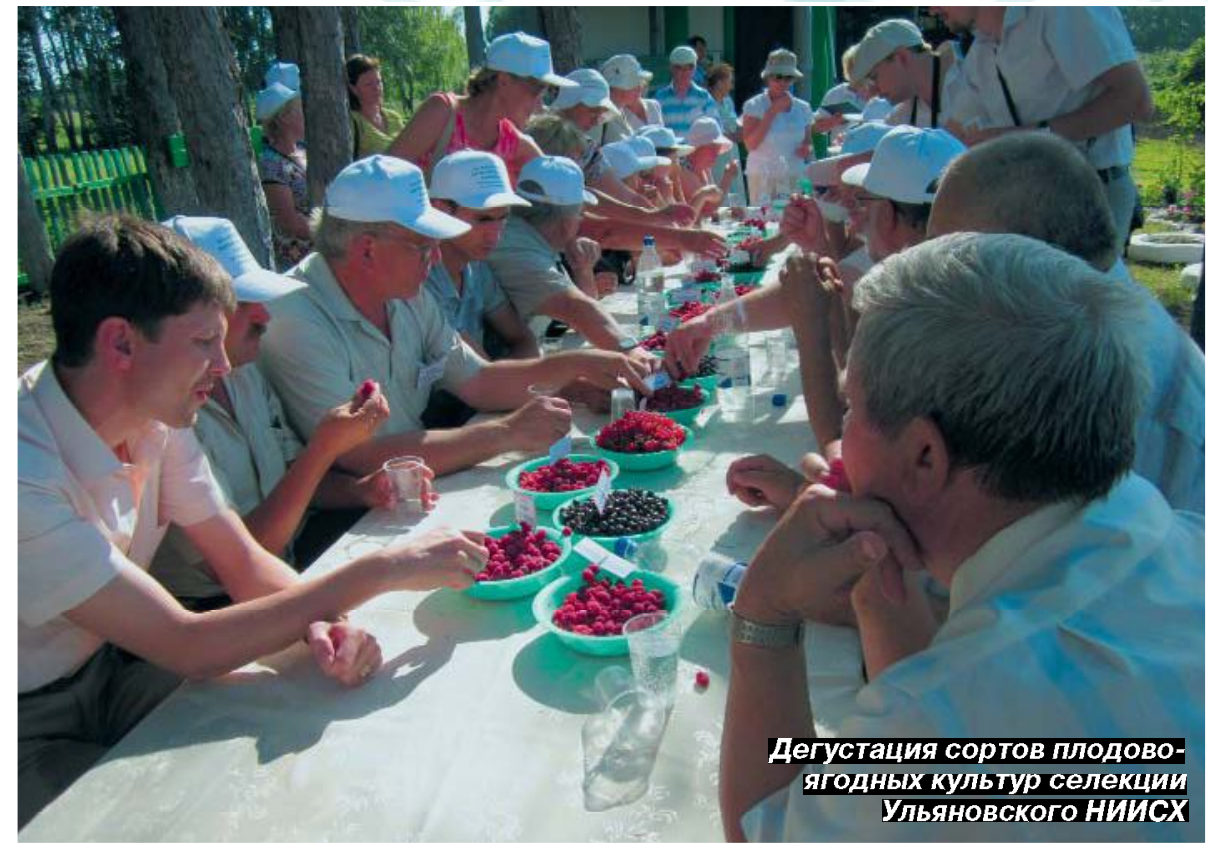

на с селекцией, генетикой, семеноводством. По этим вопросам было представлено большое число работ авторов, которые результативно проводят исследования в России и странах СНГ: Азербайджане, Белоруссии, Украине, Молдавии на сельскохозяйственных растениях, в том числе интродуцированных. Необходимо отметить активность сотрудников научно-исследовательских институтов и университета Азербайджана, а благодаря четкой организационной работе члена оргкомитета академика АНИРР к.с.-Х.н. Мусаева М.К. участники конференции позна-
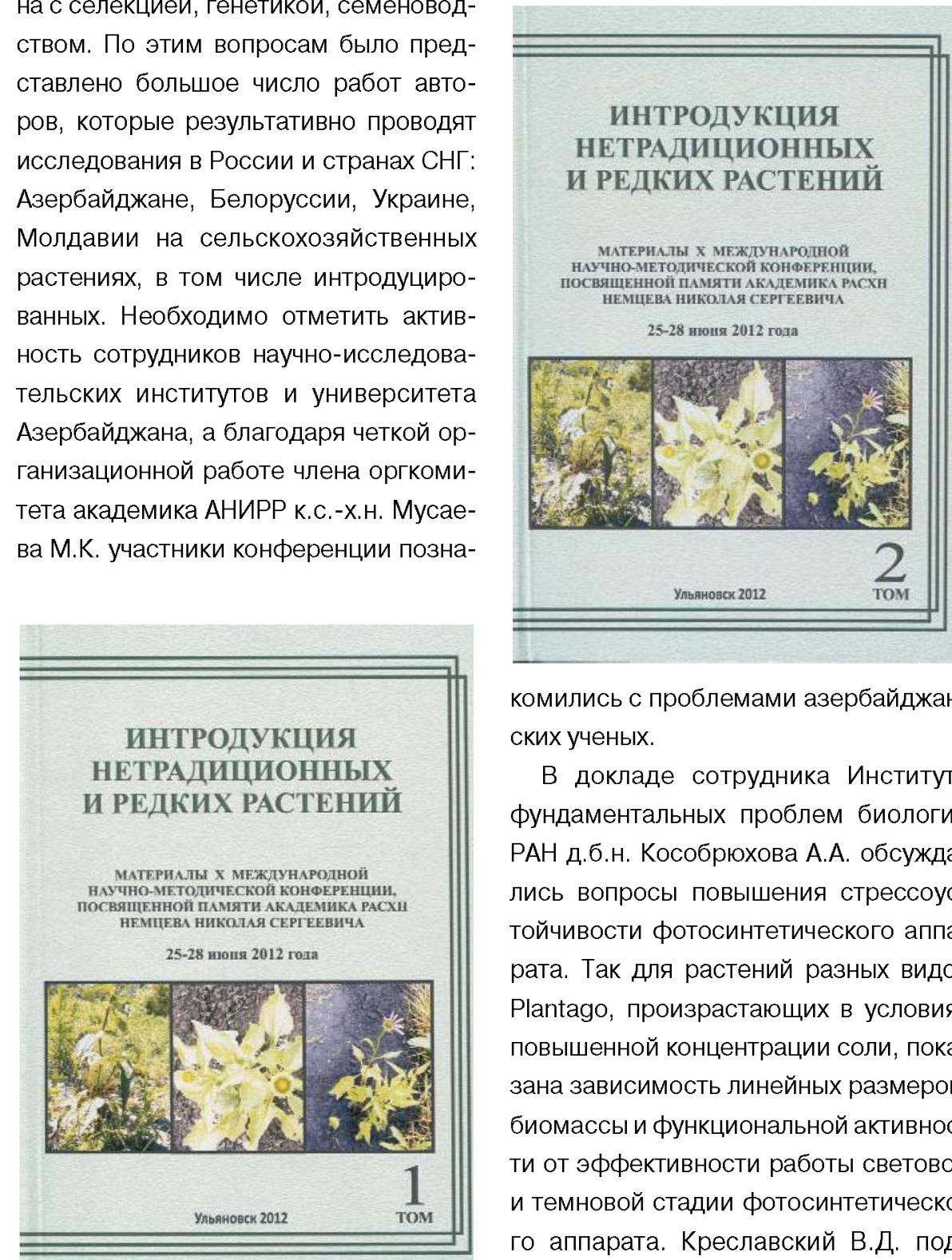

комились с проблемами азербайджанских ученых.

В докладе сотрудника Института фундаментальных проблем биологии РАН д.б.н. Кособрюхова А.А. обсуждались вопросы повышения стрессоустойчивости фотосинтетического аппарата. Так для растений разных видов Plantago, произрастающих в условиях повышенной концентрации соли, показана зависимость линейных размеров, биомассы и функциональной активности от эффективности работы световой и темновой стадии фотосинтетического аппарата. Креславский В.Д. подчеркнул, что в связи с возрастающим 


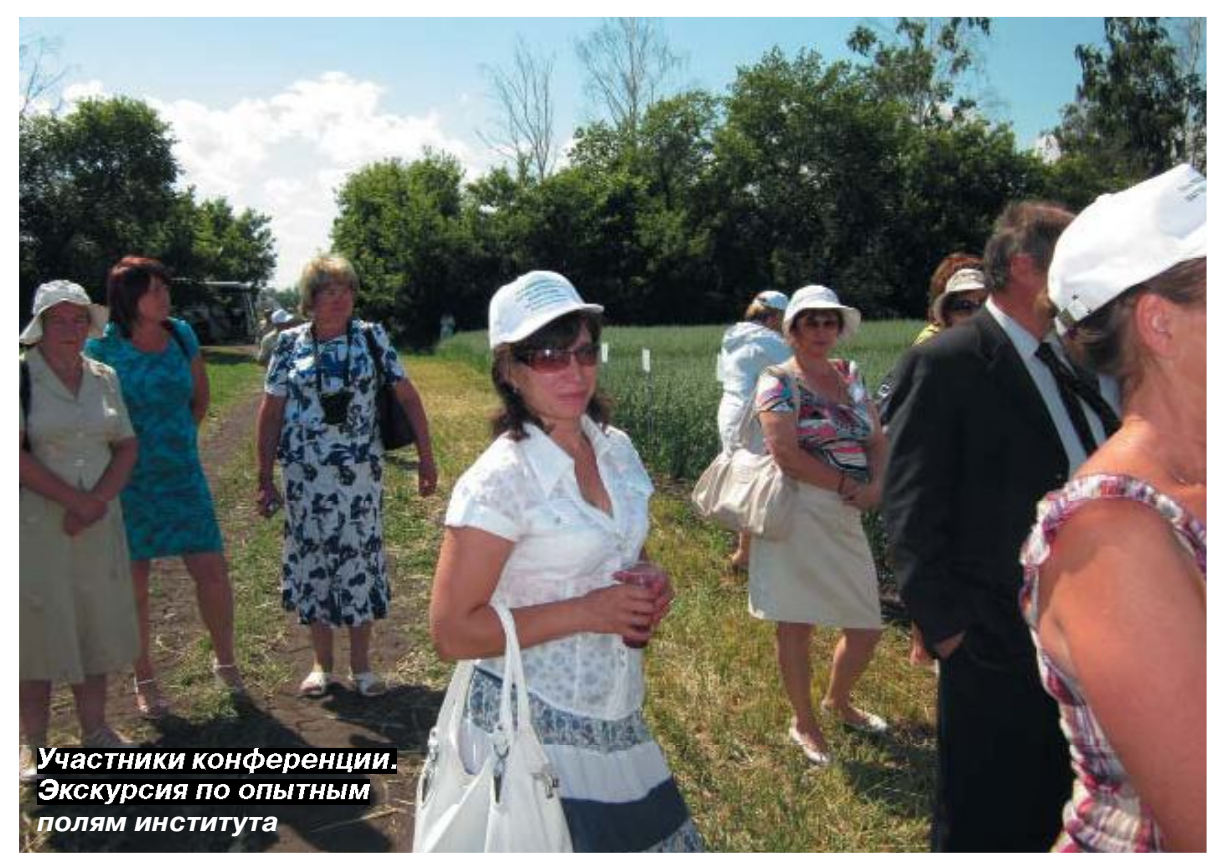

интересом к экологически устойчивым сельскохозяйственным растениям, изучение формирования защитных и адаптивных механизмов фотосинтетического аппарата при действии абиогенных стрессоров (высокоинтенсивный свет, УФ) способствует выявлению важную роль фоторецепторов красного и синего света и лучшей трансдукции фоторецепторного сигнала.

В институтах Россельхозакадемии (ВНИИССОК) проводятся исследования закономерностей накопления низкомолекулярных антиоксидантов в условиях низких положительных и отрицательных температур на растениях капусты пекинской и амаранта (доклад ст.н.с. Байкова А.А., проф. Гинс М.С., проф. Гинс В.К.).

В ВИРе (д.б.н. Тырышкин Л.Г.) совместно с Ульяновским НИИСХ (Захаровым В.Г.) и Самарским НИИСХ изучают экспрессию ювенильных LR генов устойчивости пшеницы к листовой ржавчине у взрослых растений. В результате проведенной работы был сделан вывод о невозможности предсказания полевой устойчивости к листовой ржавчине образцов пшеницы, защищенных генами, классифицируемыми как гены ювенильной устойчивости, на основе знания частот вирулентности к ним в проростковой стадии. В докладе д.б.н. Тырышкина Л.Г. прозвуработы образцы T. araraticum могут быть использованы для изучения генетического контроля устойчивости к листовой ржавчине (определение количества генов, их возможного взаимодействия) у образцов T. timopheevii.

Большой интерес вызвал доклад доцента, канд. физ.-мат. наук Кузнецовой Е.А., посвященный изучению межвидовых гибридов пихт в Ивантеевском дендропарке.

Для повышения продуктивности растений, в частности нута, характерной культуры засушливого Поволжья, сотрудники Саратовского государственного университета им. Н.И. Вавилова использовали бактериальные удобрения (экстрасол) совместно с регуляторами роста (агат 25-к). Как отметила в своем докладе д.с.-х.н. Шевцова Л.П., наибольший урожай зерна нута сформировался при использовании экстрасола при предпосевной обработке семян, который в среднем за годы испытаний составил 2,56 т/га и превысил контроль на 18,4\%.

На осушенных торфяниках лучшим способом использования трав является уборка их на сено, это способствует получению самой высокой урожайности. К такому заключению пришли авторы, что было озвучено в докладе д.с.чало, что обнаруженные в процессе х.н. Зотова А.Л., поскольку при этом наблюдается меньшее ее снижение под действием движителей сельскохозяйственной техники.

Во ВНИИ кормов им. В.Р. Вильямса В течение многих лет проводятся селекционно-генетические исследования по созданию новых синтетических популяций клевера ползучего путем подбора родительских пар для гибридизации на основе оценки их общей и специфической комбинационной способности по комплексу ценных хозяйственно-биологических признаков. В докладе В.А. Трухана отмечено, что большинство генотипов клевера ползучего (пять из шести) характеризовались высокими оценками эффектов общей комбинационной способности по отдельным или комплексу ценных показателей.

Там же, во ВНИИ кормов им. В.Р. Вильямса в результате 10-летних исследований были получены обстоятельные данные по продуктивности козлятника восточного при длительном его выращивании в Нечерноземной зоне, который представляет собой качественный корм с повышенной концентрацией сухого вещества и энергетической питательностью. Как отмечено докладчиком к.с.-Х.Н. Л.А. Трузиной, продуктивность козлятника восточного увеличивается с возрастом травостоя.

В работе конференции участвовали аспиранты РАН и Россельхозакадемии. Обстоятельный доклад сделала Черкашина И.А. (Тобольская комплексная научная станция Уральского отделения РАН): оценка структурно-функционального состояния Triticum aestivum L. по показателям ассимиляционной поверхности флаговых листьев.

По материалам конференции выпущено 2 сборника научных трудов $\mathrm{X}$ Международной научно-методической конференции, посвященной памяти академика Россельхозакадемии Немцева Н.С., в которых опубликовано более 500 работ, общим объемом 64 усл. печ. листа. 


\section{ИНФОРМАЦИОННЫЕ СООБЩЕНИЯ}

\section{ПАМЯТИ НЕМЦЕВА Н.С.}

$\mathrm{B}$ июне 2012 года состоялась X Международная научно-методическая конференция, посвященная светлой памяти бывшего директора Ульяновского научно-исследовательского института сельского хозяйства, академика Российской академии сельскохозяйственных наук, доктора сельскохозяйственных наук, профессора, Лауреата Государственной премии Российской Федерации в области науки и техники, заслужен-ного агронома РФ, члена Политсовета партии «Единая Россия», Почётного гражданина Ульяновской области Немцева Николая Сергеевича.

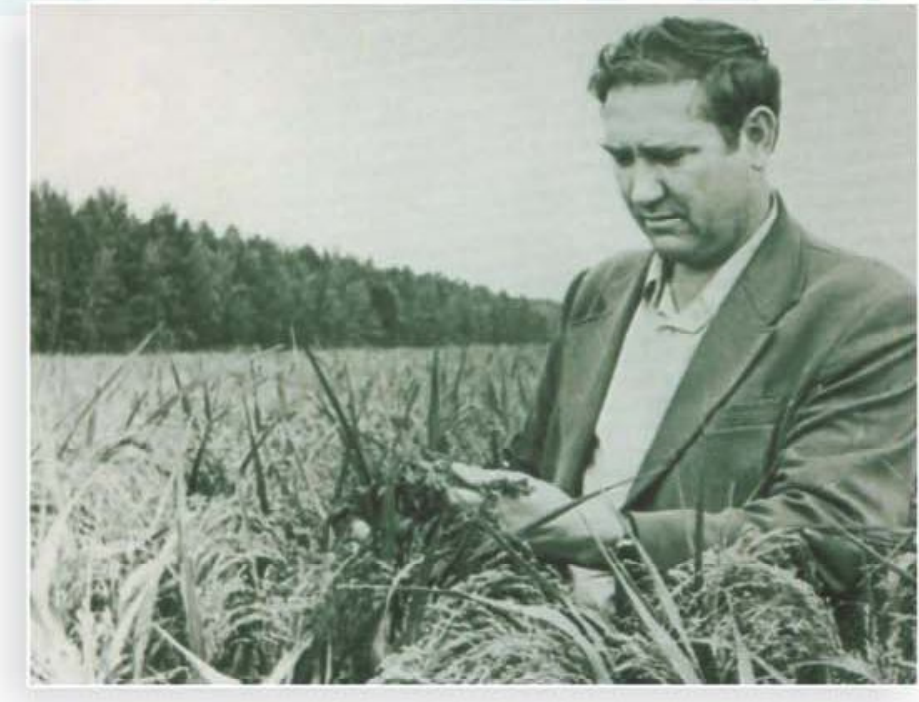

Пройденный им жизненный путь от агронома-семеновода ОПХ «Тимирязевское» до руководителя одного из ведущих научных учреждений Отделения земледелия Россельхозакадемии, от ученого агронома до академика РАСХН является примером беззаветного служения аграрной науке и сельскохозяйственному производству.

Академик Н.С. Немцев - известный учёный в области земледелия, который внёс значительный вклад в разработку почвозащитной системы земледелия Среднего Поволжья, разработал и внедрил энергосберегающие способы обработки почвы. Впервые в лесостепной зоне Поволжья обосновал и дал агроэкологическую оценку чередования отвальных и поверхност-

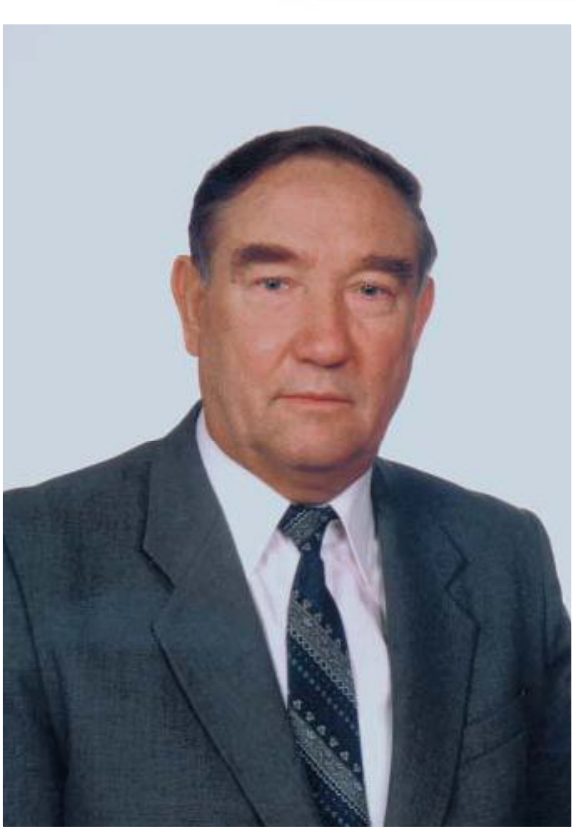

Работая более 30 лет директором Ульяновского НИИСХ, проявил себя крупным организатором науки, принципиальным руководителем, умеющим организовать и нацелить коллектив на выполнение поставленных задач. Уделял большое внимание созданию в институте научного потенциала, укреплению материально-технической базы науки, строительству благоустроенного жилья.

Эрудированность, большой опыт и активная жизненная позиция помогли ему с успехом реализовать богатый творческий потенциал в любом деле, которым приходилось заниматься. Коллеги, ных обработок почвы в севооборотах, установил оптимальные параметры агрофизических свойств почвы при различных обработках, нашел подходы к минимализации и снижению энергоемкости основной обработки почвы.

Немцев Н.С. в соавторстве с другими известными учеными, разработал «Научные основы формирования экологически сбалансированных высокопродуктивных агроландшафтов и систем земледелия», за что был удостоен Государственной премии Российской Федерации в области науки и техники (2000 г.).

друзья, родные и близкие знали его как прекрасного человека, крупного ученого, мудрого наставника. Высоко ценились личные качества Николая Сергеевича - трудолюбие, душевная простота, теплота и человечность в отношениях с окружающими.

Николай Сергеевич - большой учёный, крупный организатор науки производства, замечательный человек навсегда останется в памяти колле благодарных учеников и научного сообщества, всех, кто его знал.

\section{Литература}

1. Интродукция нетрадиционных растений: материалы Х Международной научно-методической конференции, посвященной памяти академика РАСХН Немцева Николая Сергеевича. 25-28 июня 2012 года / под ред. д-ра с.-х. наук С.Н. Немцева. В 2 т. Т.1. - Ульяновск: УлгТУ, 2012.-528 с.

2. Интродукция нетрадиционных растений: материалы Х Международной научно-методической конференции, посвященной памяти академика РАСХН Немцева Николая Сергеевича. 25-28 июня 2012 года / под ред. д-ра с.-х. наук С.Н. Немцева. В 2 т. Т.2. - Ульяновск: УлГТУ, 2012.-561 с. 